\title{
Urgences
}

\section{Ici et là}

\section{Jean-Paul Daoust}

Numéro 15, octobre 1986

Épigraphiques

URI : https://id.erudit.org/iderudit/025319ar

DOI : https://doi.org/10.7202/025319ar

Aller au sommaire du numéro

Éditeur(s)

Urgences

\section{ISSN}

0226-9554 (imprimé)

1927-3924 (numérique)

Découvrir la revue

Citer ce document

Daoust, J.-P. (1986). Ici et là. Urgences, (15), 54-54.

https://doi.org/10.7202/025319ar

Ce document est protégé par la loi sur le droit d'auteur. L'utilisation des services d'Érudit (y compris la reproduction) est assujettie à sa politique d'utilisation que vous pouvez consulter en ligne.

https://apropos.erudit.org/fr/usagers/politique-dutilisation/ 


\section{Jean-Paul Daoust \\ ICI ET LÄ}

Even in the afternoon Detroit is dangerous.

Ed Koch (maire de New York): Detroit Free Press (17 juillet 1986)

Vienne ses Cafés

L'or de Klimt

Cadillac City Michigan Hot Dogs

Art Nouveau

$G$ enerous $M$ otor

Les constructions freudiennes

Ford

Detroit is THE Dangerous Town

Centre Ville poli

From Strauss

Walk at your own risk

Sightseeing with Falco

To Motown

The heavy beat of Detroit

Dans chaque case du temps un symbole question de soleils pointus qui gravent nos corps exaltés écritures visuelles boire la lumière des meilleurs vins le maquillage comme une belle pourriture chaque gouttelette de temps brûle nos peaux la vie voyage en fait des papyrus incrustés d'or

M. et Moi

Vienne

Juin
1986
Des amants américains

Houghton Lake, Michigan.

Juillet

Jean-Paul Daoust 